\title{
Survey on European Studies of the Chemical Characterisation of Tattoo Ink Products and the Measurement of Potentially Harmful Ingredients
}

\author{
Manuela Agnello • Marco Fontana \\ ARPA Piemonte, Regional Agency of Environmental Protection, Igiene Industriale, Grugliasco, Italy
}

\begin{abstract}
The results of the detection of carcinogenic aromatic amines in about 300 ink samples are discussed. All analysed inks contained at least one or more azo compound pigments, and the presence of aromatic amines could only have originated from these compounds through a chemical process named 'reductive cleavage'. Sometimes, aromatic amines were also present as impurities derived from the processing of the pigments. A systematic surveillance programme in Italy, promoted by the Italian Ministry of Health with the involvement of Italian regions, local public health authorities and Agenzia Regionale per la Protezione Ambiente del Piemonte (Environmental Protection Agency), has shown that about $40 \%$ of the monitored inks are not regular according to European Resolution ResAP(2008):1. The method utilised for the detection of aromatic amines has allowed the identification of other substances that are not carcinogenic but are toxic or have sensitisation properties that are derived from reductive cleavage or that are present as impurities.

(c) 2015 S. Karger AG, Basel
\end{abstract}

\section{Introduction}

Since the end of the 1990s, the tattoo fashion has spread widely all over the world. Due to this growth and the lack of information about the substances contained in tattoo inks, in 2006, Regione Piemonte, with the cooperation of Agenzia Regionale per la Protezione Ambiente del Piemonte (ARPA Piemonte), which is an Environmental Protection Agency, and some local public health authorities, promoted a programme for the surveillance of chemicals to ensure the safety of tattoos and permanent make-up.

Local public health authorities and ARPA Piemonte defined a protocol for the inspection of tattoo parlours in Piemonte and included sampling criteria for the products used for tattooing. After a monitoring period, this team found out that the information available for the ingredients contained in tattoo inks was very poor and confusing. A significant number of safety data sheets or technical data sheets that were available at the 
monitored tattoo parlours were not updated with the current Italian legislations or did not correspond to the products present in the parlours. Analytical studies performed on 30 samples of tattoo inks in 2006-2007 showed that about 40\% of the samples were not regular according to European resolution ResAP(2003):2 [1] on tattoos and permanent make-up.

Due to these analytical results, the Italian Ministry of Health has promoted Regione, a national, systematic surveillance programme that samples tattoo inks, since 2009. Surveillance is also conducted by other authorities, such as Nucleo Anti Sofisticazioni - Carabinieri Force, custom agencies and local public health authorities. The analysis of samples is performed by a network of laboratories comprising the Istituto Superiore di Sanità (National Institute of Health) and specialised regional public laboratories according to different analytical methods and chemical matrices.

The legislative instrument utilised in Italy is EU Directive 2001/95/CEE [2], with application of the update for consumer protection (D. Lgs 'Codice del Consumo') n²06 of 2005. This legislation guarantees the safety of all products placed in the Italian market and allows for the application of Resolution ResAP(2008):1 [1] (which supersedes Resolution ResAP(2003):2 on tattoos and permanent make-up) and the development of a surveillance system coordinated by the Ministry of Health. In addition, the Registration, Evaluation, Authorisation and Restriction of Chemicals regulation $\mathrm{n}^{\circ} 1907 / 2006$ and the Classification, Labelling and Packaging regulation $\mathrm{n}^{\circ} 1272 / 2008$ provide some restrictions for dangerous substances as well as specific rules for the classification and labelling of substances, mixtures and articles.

The notification system Rapid Information System for Non-food Products is the instrument used in the EU for sharing information about the irregularity of products among local authorities, consumers, producers and users. This system is currently used in Italy.

\section{Ink Characterisation}

Tattoo inks consist of pigments combined with a carrier.

Tattoo inks are available in a range of colours that can be thinned or mixed to produce other colours and shades. Most professional tattoo artists purchase pre-made inks (known as pre-dispersed inks), while some tattooists mix their own ink using a dry pigment and a carrier.

Pigments are chemically derived from three main groups of vegetal, inorganic or organic origin.

Vegetal pigments are often derived from root plants or logwood, which is a heartwood extract from 'Haematoxylon campechisnum' that is found in Central America and the West Indies. The most-used black inks are made of Carbon Black (CI 77266), but it is sometimes possible to find black inks made of dried vegetal algae dispersed in a carrier.

Inorganic pigments are made from minerals such as magnetite $\left(\mathrm{Fe}_{3} \mathrm{O}_{4}\right.$ or $\left.\mathrm{FeO}\right)$ and are often associated with brown and dark colours. Cinnabar ( $\mathrm{HgS})$ is used for red colours, and other kinds of inorganic compounds, such as various metal oxides or sulphides, are used for a wide range of colours. Titanium oxides $\left(\mathrm{TiO}_{2}\right)$ are commonly used as white pigments.

The organic pigments are the most variable group and include some different chemical classes that are dependent on characteristic functional groups:

- Nitro dye, associated with yellow colours.

- Xanthenic dye, associated with various colours, mainly various shades of yellow.

- Phtalocyanine compounds, associated with blue and green colours.

- Antraquinone dyes, associated with red and brown colours.

- Mono-azo and di-azo dyes, commonly known as azo dyes. These pigments are used for various colours such as yellow, red or orange.

The colorants (both dyes and pigments) are listed by their colour index numbers. The colour 
Table 1. Colour index numbers

\begin{tabular}{ll}
\hline Structure & Colour index range \\
\hline Nitroso & $10000-10299$ \\
Nitro & $10300-10999$ \\
Monoazo & $11000-19999$ \\
Diazo & $20000-39999$ \\
Stilbene & $40000-41999$ \\
Diarylmethane & $41000-41999$ \\
Triarylmethane & $42000-44999$ \\
Xanthene & $45000-45999$ \\
Acridine & $46000-46999$ \\
Quinoline & $47000-47999$ \\
Methine & $48000-48999$ \\
Thiazole & $49000-49399$ \\
Indamine & $49400-49699$ \\
Indophenol & $49700-49999$ \\
Azine & $50000-50999$ \\
Oxazine & $51000-51999$ \\
Thiazine & $52000-52999$ \\
Aminoketone & $56000-56999$ \\
Anthraquinone & $57000-72999$ \\
Indigoid & $73000-73999$ \\
Phtalocyanine & $74000-74999$ \\
Natural dyes & $75000-76999$ \\
Inorganic pigments & $77000-77999$ \\
\hline
\end{tabular}

index numbers are grouped into ranges according to their chemical structure, as shown in table 1 .

\section{Aromatic Amines in Azo Dyes}

Azo compounds are by far the most widely used synthetic organic colorants. The colour index lists more than 2,000 azo compounds. Azo dyes are generally synthesised starting from primary aromatic amines that are diazotisated and coupled with phenols or secondary aromatic amines. In fact, the main chromophore group of the azo compounds is the diarylazo group $(\mathrm{Ar}-\mathrm{N}=$ $\mathrm{N}$-Ar'), which is derived from simpler molecules known as aromatic amines.

Commercial products often contain high levels of other components that are especially rele- vant from a toxicological point of view: the aromatic amines, which are chemically characterised by a $\mathrm{NH}_{2}$ group and are often found in inks as contaminants or reduction (cleavage) products.

According to some studies [3-6], aromatic amines can be formed by the reductive cleavage of azo compounds by human enzymes over a varying range of time beginning from the introduction of the pigments under the skin. Figure 1 shows a hypothetical example: pigment red 5 could be cleaved into three aromatic amines, two of which, $\mathrm{p}$-cresidine and o-toluidine, are carcinogenic.

The chemical analysis discussed in this work focuses on inks containing at least one azo compound and on the determination of certain carcinogenic aromatic amines that could derived from pigment decomposition by means of reductive cleavage.

The aromatic amines that were detected, with their classifications assigned according to regulations by Classification, Labelling and Packaging [7] and other institutions, such as the International Agency for Research on Cancer and the American Conference of Governmental Industrial Hygienists $[8,9]$, are listed in table 2.

According to Resolution ReSAP(2008): 1, these aromatic amines '...particularly with regard to their carcinogenic, mutagenic, reprotoxic and sensitising properties, ... should neither be present in tattoos and PMU products nor released from azocolorants'.

The limit of quantification of the method used for the determination of the aromatic amines is $1 \mathrm{mg} / \mathrm{kg}$ for each substance listed in table 2. Traces of aromatic amines below this limit of quantification are not considered.

\section{Methodology}

The chemical analysis carried out by Arpa Piemonte mainly focused on synthetic pigments specially derived from azo compounds. About 


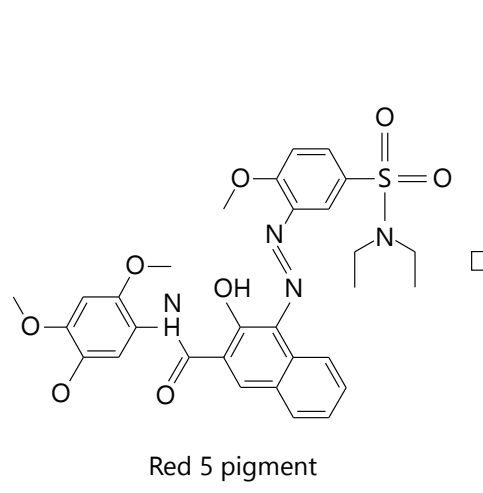<smiles>Nc1cccc(Cl)c1</smiles>

m-chloroaniline<smiles>C1=CCCC1</smiles><smiles>COc1ccc(C)cc1N</smiles><smiles>Cc1ccccc1N</smiles>

o-toluidine

p-cresidine

Fig. 1. Cleavage reduction of red 5.

Table 2. List of detected aromatic amines

\begin{tabular}{|c|c|c|c|}
\hline \multirow[t]{2}{*}{ Substances [CAS number] } & \multicolumn{3}{|c|}{ Carcinogenic classifications } \\
\hline & IARC & ACGIH & CLP \\
\hline o-Toluidine [95-53-4] & $2 \mathrm{~A}$ & A3 & Carc. $1 \mathrm{~B}-\mathrm{H} 350$ \\
\hline o-Anisidine [90-04-0] & $2 \mathrm{~B}$ & A3 & Carc. 1B - H350 \\
\hline 4-Chloroaniline [106-47-8] & $2 \mathrm{~B}$ & - & Carc. 1B - H350 \\
\hline 6-Methoxy-m-toluidine [120-71-8] & $2 \mathrm{~B}$ & - & Carc. 1B- H350 \\
\hline 2,4,5-Trimethylaniline [137-17-7] & 3 & - & Carc. 1B - H350 \\
\hline 4-Chloro-o-toluidine [95-69-2] & $2 \mathrm{~A}$ & - & $\begin{array}{l}\text { Carc. 1B - H350 } \\
\text { Muta. } 2-\mathrm{H} 341\end{array}$ \\
\hline 4-Methyl-m-phenylenediamine [95-80-7] & $2 \mathrm{~B}$ & - & $\begin{array}{l}\text { Carc. 1B - H350 } \\
\text { Muta. } 2 \text { - H341 } \\
\text { Repr. } 2 \text { - H361f }\end{array}$ \\
\hline 4-Methoxy-m-phenylenediamine [615-05-4] & $2 \mathrm{~B}$ & - & $\begin{array}{l}\text { Carc. 1B - H350 } \\
\text { Muta. } 2-\mathrm{H} 341\end{array}$ \\
\hline 2-Naphthylamine [91-59-8] & 1 & A1 & Carc. $1 \mathrm{~B}-\mathrm{H} 350$ \\
\hline Biphenyl-4-ylamine [92-67-1] & 1 & A1 & Carc. 1B - H350 \\
\hline $4,4^{\prime}-$ Oxydianiline $[101-80-4]$ & $2 \mathrm{~B}$ & - & $\begin{array}{l}\text { Carc. 1B - H350 } \\
\text { Muta. } 2 \text { - H341 } \\
\text { Repr. } 2 \text { - H361f }\end{array}$ \\
\hline Benzidine [92-87-5] & 1 & $\mathrm{~A} 1$ & Carc. 1B - H350 \\
\hline 4,4'-Methylenedianiline [101-77-9] & $2 \mathrm{~B}$ & A3 & $\begin{array}{l}\text { Carc. 1B - H350 } \\
\text { Muta. } 2 \text { - H341 }\end{array}$ \\
\hline 4,4'-Methylenedi-o-toluidine [838-88-0] & $2 \mathrm{~B}$ & - & Carc. 1B-H350 \\
\hline 3,3'-Dimethylbenzidine [119-93-7] & $2 \mathrm{~B}$ & A3 & Carc. 1B - H350 \\
\hline 4,4'-Thiodianiline [139-65-1] & $2 \mathrm{~B}$ & - & Carc. 1B - H350 \\
\hline 3,3'-Dichlorobenzidine [91-94-1] & $2 \mathrm{~B}$ & A3 & Carc. 1B- H350 \\
\hline 4,4'-Methylenebis(2-chloroaniline) [101-14-4] & $2 \mathrm{~A}$ & $\mathrm{~A} 2$ & Carc. 1B - H350 \\
\hline 3,3'-Dimethoxybenzidine [119-90-4] & $2 \mathrm{~B}$ & - & Carc. 1B-H350 \\
\hline 5-Nitro-o-toluidine [99-55-8] & 3 & A3 & Carc. 1B - H351 \\
\hline o-Aminoazotoluene [97-56-3] & $2 \mathrm{~B}$ & - & Carc. 1B - H351 \\
\hline 4-Aminoazobenzene [60-09-3] & $2 \mathrm{~B}$ & - & Carc. 1B-H351 \\
\hline
\end{tabular}


Table 3. Comparison of two methods

\begin{tabular}{lll}
\hline Inks & $\begin{array}{l}\text { O-anisidine with } \\
\text { ISO 17234 } \mathrm{mg} / \mathrm{kg}\end{array}$ & $\begin{array}{l}\text { O-anisidine with } \\
\text { ISO 14362 } \mathrm{mg} / \mathrm{kg}\end{array}$ \\
\hline Yellow 1 & 318 & 46 \\
Yellow 2 & 177 & 11 \\
Yellow 3 & 242 & 78 \\
Yellow 4 & 113 & 18 \\
Yellow 5 & 69 & 32 \\
\hline
\end{tabular}

300 ink samples of various colours were analysed for the determination of aromatic amines.

The analytical method was derived from EN ISO 17234 [10], which is normally used for the determination of aromatic amines in leather samples. The method consists of three stages:

(1) Chemical reduction of pigments with sodium dithionite as a reduction agent.

(2) Extraction of aromatic amines that could be formed by sodium dithionite by means of methyl tert butyl ether.

(3) Quantitative analysis by gas chromatography followed by mass spectrometry.

The method used for leather samples was adapted to ink samples and then compared to the method described in ResAP, which was derived from the determination of aromatic amines in textiles (ISO 14362 - Textiles. Methods for the determination of certain aromatic amines derived from azo colorants. Detection of certain azo colorants that are accessible with and without extracting the fibres) [11].

These two methods are rather similar, except for the first step, the pigment reduction. The concentration of sodium dithionite in ISO 17234 is about $200 \mathrm{mg} / \mathrm{ml} ; 3 \mathrm{ml}$ of this solution is added to the samples, and the samples are pre-heated for $20 \mathrm{~min}$ at $70^{\circ} \mathrm{C}$ in $17 \mathrm{ml}$ of citrate buffer at $\mathrm{pH} 6$ for other $20 \mathrm{~min}$.

In the model method derived from ISO 14362, $5 \mathrm{ml}$ of dithionite solution (5\%) in phosphate buffer is added to the sample. Then, the reduction continues at $70^{\circ} \mathrm{C}$ for $90 \mathrm{~min}$.
The leather method is more effective when compared to this method, but its application is in agreement with the directives of the Ministry of Heath, which are based on a 'precaution principle'.

Table 3 shows the concentrations of o-anisidine in a group of samples, compared to the above-described methods. The classification of these samples does not conform to Resolution ResAP(2008): 1 when both methods are considered.

\section{Data Evaluation}

The analytical results of the detection of carcinogenic aromatic amines in about 300 samples showed the presence of carcinogenic compounds in more than $40 \%$ of the inks that were considered [12].

Higher irregularities were found in yellow and red colours and related shades, such as orange, flesh and green (green colour is sometimes derived from blue pigment mixed with yellow pigment).

The aromatic amines that were frequently determined were o-toluidine, which was found in 24 samples; o-anisidine, which was found in 64 samples; 4-chloroaniline (also known as p-chloroaniline), which was found in 5 samples; $3,3^{\prime}$-dichlorobenzidine, which was found in 6 samples; 5-nitro-o-toluidine (also known as 2-methyl5-nitroaniline), which was found in 5 samples; and 4-methyl-m-phenylenediamine (also known as 2,4-diaminotoluene), which was found in 4 samples. Often, the reduction split the pigments into more than one aromatic amine; therefore, two or more aromatic amines were detected in a significant number of irregular samples. In a red sample, 5 different carcinogenic aromatic amines were found.

The aromatic amines that were most frequently detected were o-toluidine, which is generally related to red colours, and o-anisidine, which is generally related to yellow colours.

The amounts of the aromatic amines that were found were quite variable, and a graphical representation is shown in figure 2 . 


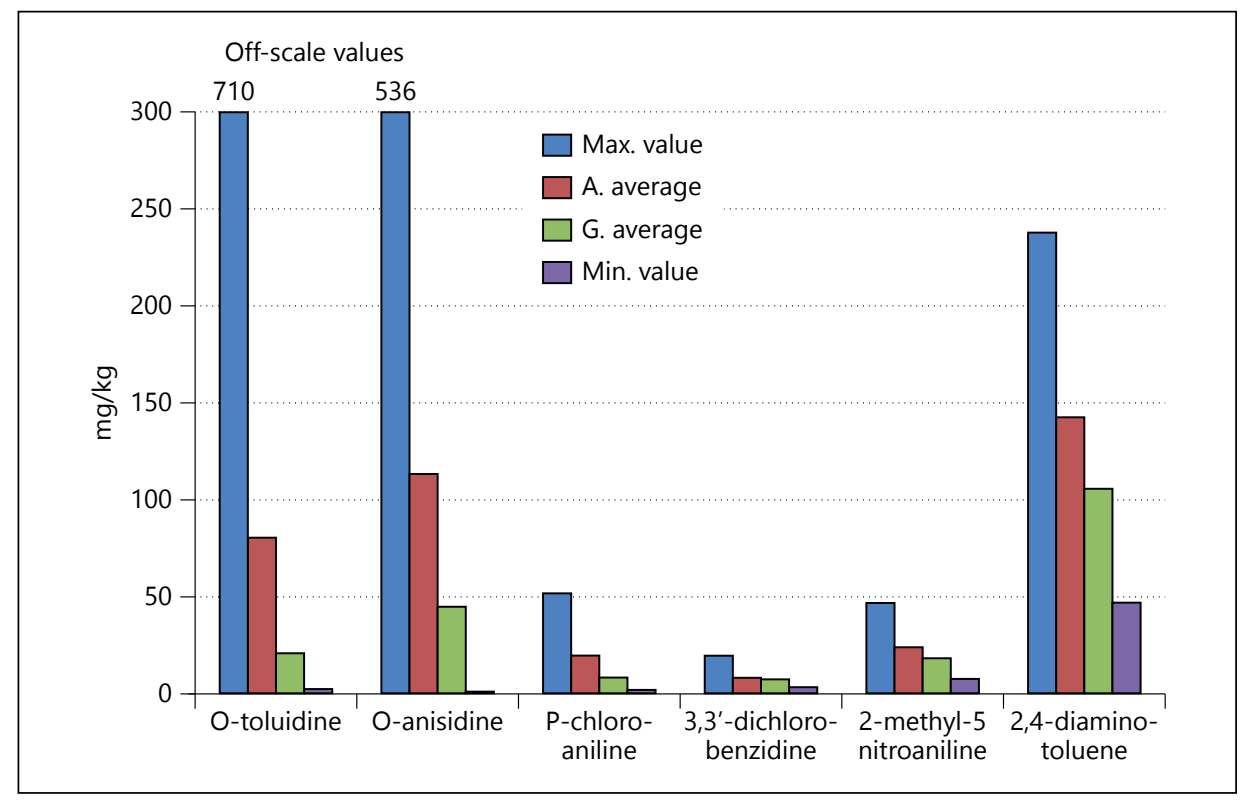

Fig. 2. Statistical evaluation of the detected concentrations of aromatic amines.

A very large number of irregular samples contained a considerable amount of aromatic amines, and in about $44 \%$ of the irregular samples, these quantities exceeded $100 \mathrm{mg} / \mathrm{kg}$ (see fig. 3). The highest concentration was found in a shade of red: up to $700 \mathrm{mg} / \mathrm{kg}$ of o-toluidine. Furthermore, a shade of yellow had about $550 \mathrm{mg} / \mathrm{kg}$ of o-anisidine (see fig. 2).

Despite the strong reduction of the azo compound pigments, a significant percentage didn't show the presence of carcinogenic aromatic amines. This fact shows that it is possible to produce safe inks containing azo compound pigments.

\section{Considerations}

Our results led us to affirm that the determination of aromatic amines mostly depends on the specific lot number. In fact, some inks of the same brand and colour showed different results.
Table 4 shows some examples: the green, orange and yellow inks that were analysed could be either regular or irregular, based on the lot number.

The origin of the pigments is probably the key. Even though producers always use chemically equal pigments during the production of the various ink lots, the country of origin and the quality of the pigments could differ from one to the other.

One more test was carried out on two equal orange samples that had the same lot number. The analysis showed different results: one sample was regular, and the other one wasn't (see table 4, first row).

When investigating this peculiar case, the irregular sample that had a remarkable amount of o-toluidine was identified as a fake. The label was counterfeit and didn't correspond to the real product. It had been falsified. This situation represents a further danger in the production of tattoo inks and in the safety of customers.

Moreover, qualitative screening performed with the same method used for the determination 
Fig. 3. Distribution of amounts of aromatic amines in different ranges of concentrations.

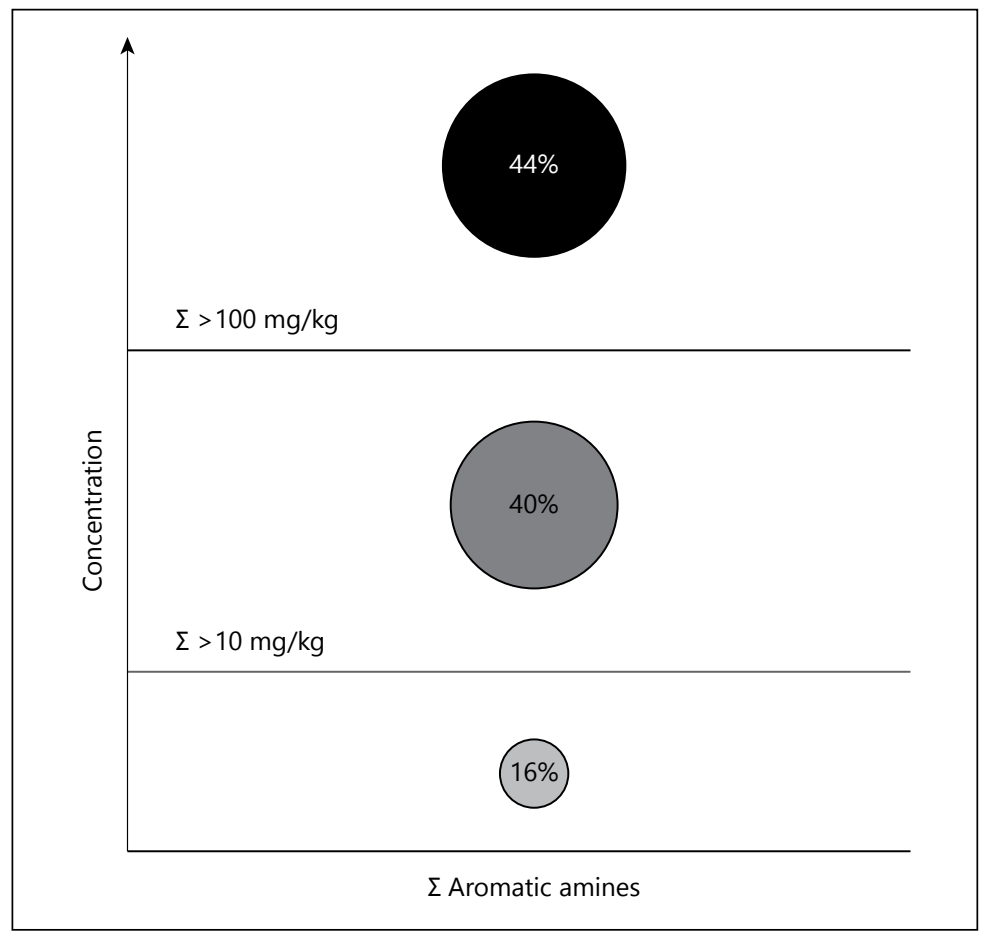

Table 4. Conformity by lot number

\begin{tabular}{|c|c|c|}
\hline $\begin{array}{l}\text { Orange ink - Brand A } \\
\left.\text { (Lot } N^{\circ} A B X X X 10\right) \\
\text { Irregular } \\
3,3^{\prime} \text {-dichlorobenzidine }\end{array}$ & $\begin{array}{l}\text { Orange ink - Brand A } \\
\text { (Lot } \mathrm{N}^{\circ} \mathrm{ABXXX09)} \\
\text { Irregular } \\
\text { O-toluidine }\end{array}$ & $\begin{array}{l}\text { Orange ink - Brand A } \\
\left.\text { (Lot } N^{\circ} A B X X X 09\right) \\
\text { Regular }\end{array}$ \\
\hline 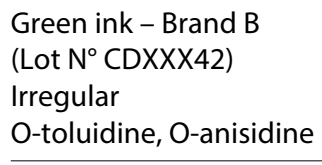 & $\begin{array}{l}\text { Green ink - Brand B } \\
\text { (Lot N }{ }^{\circ} \text { CEXXX04) } \\
\text { Regular }\end{array}$ & \\
\hline $\begin{array}{l}\text { Yellow ink - Brand C } \\
\text { (Lot } N^{\circ} \text { FGXXX88) } \\
\text { Irregular } \\
\text { O-anisidne }\end{array}$ & $\begin{array}{l}\text { Yellow ink - Brand C } \\
\text { (no lot number) } \\
\text { Regular }\end{array}$ & \\
\hline
\end{tabular}

of carcinogenic aromatic amines revealed that other compounds, including aromatic amines that were not carcinogenic but were toxic (see table 5), were found in about $30 \%$ of the samples, both regular and irregular.

\section{Future Developments}

The evaluation of risks associated with the use of inks for tattoos carried out in recent years has allowed a frequent exchange of experiences at the Italian and European levels. 
Table 5. $\mathrm{H}$ phrases about chemical substances found in the qualitative analyses

\begin{tabular}{|c|c|}
\hline Substances [CAS number] & $\begin{array}{l}\text { H phrases and notes from the American Conference of Governmental and } \\
\text { Industrial Hygienists and the International Agency for Research on Cancer }\end{array}$ \\
\hline $\begin{array}{l}\text { Aniline } \\
{[62-53-3]}\end{array}$ & $\begin{array}{l}\text { H351 Suspected of causing cancer } \\
\text { H341 Suspected of causing genetic defects } \\
\text { H331 Toxic if inhaled } \\
\text { H311 Toxic when in contact with skin } \\
\text { H301 Toxic if swallowed } \\
\text { H372 Causes damage to organs through prolonged or repeated exposure } \\
\text { H318 Causes serious eye damage } \\
\text { H317 May cause an allergic skin reaction } \\
\text { H400 Very toxic to aquatic life } \\
\text { ACGIH: Skin, A3 }\end{array}$ \\
\hline $\begin{array}{l}\text { 2-Ethoxyaniline } \\
\text { [94-70-2] }\end{array}$ & $\begin{array}{l}\text { H331 Toxic if inhaled } \\
\text { H311 Toxic when in contact with skin } \\
\text { H301 Toxic if swallowed } \\
\text { H372 Causes damage to organs through prolonged or repeated exposure }\end{array}$ \\
\hline $\begin{array}{l}\text { 3,4-Dichlorobenzenamine } \\
\text { [95-76-1] }\end{array}$ & $\begin{array}{l}\text { H331 Toxic if inhaled } \\
\text { H311 Toxic when in contact with skin } \\
\text { H301 Toxic if swallowed } \\
\text { H317 May cause an allergic skin reaction } \\
\text { H318 Causes serious eye damage } \\
\text { H400 Very toxic to aquatic life } \\
\text { H410 Very toxic to aquatic life with long-lasting effects }\end{array}$ \\
\hline $\begin{array}{l}\text { 4-Ethoxyaniline } \\
{[156-43-4]}\end{array}$ & $\begin{array}{l}\text { H341 Suspected of causing genetic defects } \\
\text { H322 May be harmful if inhaled } \\
\text { H312 Harmful when in contact with skin } \\
\text { H302 Harmful if swallowed } \\
\text { H319 Causes serious eye irritation } \\
\text { H317 May cause an allergic skin reaction }\end{array}$ \\
\hline $\begin{array}{l}\text { N-Isopropyl-N'-phenyl-p- } \\
\text { phenylendiamine (IPPD) } \\
{[101-72-4]}\end{array}$ & $\begin{array}{l}\text { H302 Harmful if swallowed } \\
\text { H317 May cause an allergic skin reaction } \\
\text { H400 Very toxic to aquatic life } \\
\text { H410 Very toxic to aquatic life with long-lasting effects }\end{array}$ \\
\hline $\begin{array}{l}\text { Styrene } \\
{[100-42-5]}\end{array}$ & $\begin{array}{l}\text { H226 Flammable liquid and vapour } \\
\text { H332 May be harmful if inhaled } \\
\text { H319 Causes serious eye irritation } \\
\text { H315 Causes skin irritation } \\
\text { IARC NOTE: 2B (possibly carcinogenic) }\end{array}$ \\
\hline $\begin{array}{l}\text { 3-Butenylbenzene } \\
\text { [768-56-9] }\end{array}$ & $\begin{array}{l}\text { H315 Causes skin irritation } \\
\text { H411 Toxic to aquatic life with long-lasting effects }\end{array}$ \\
\hline $\begin{array}{l}\text { Biphenyl } \\
{[92-52-4]}\end{array}$ & $\begin{array}{l}\text { H319 Causes serious eye irritation } \\
\text { H335 May cause respiratory irritation } \\
\text { H315 Causes skin irritation } \\
\text { H400 Very toxic to aquatic life } \\
\text { H410 Very toxic to aquatic life with long-lasting effects }\end{array}$ \\
\hline
\end{tabular}


Table 5. Continued

\begin{tabular}{ll}
\hline Substances [CAS number] & $\begin{array}{l}\text { H phrases and notes from the American Conference of Governmental and } \\
\text { Industrial Hygienists and the International Agency for Research on Cancer }\end{array}$ \\
\hline Thymol & H302 Harmful if swallowed \\
[89-83-8] & H314 Causes severe skin burns and eye damage \\
& H411 Toxic to aquatic life with long-lasting effects \\
\hline 1,2-Dichlorobenzene & H302 Harmful if swallowed \\
[95-50-1] & H319 Causes serious eye irritation \\
& H335 May cause respiratory irritation \\
& H315 Causes skin irritation \\
& H400 Very toxic to aquatic life \\
& H410 Very toxic to aquatic life with long-lasting effects \\
\hline 3,4-Dichlorobenzene & H331 Toxic if inhaled \\
[95-76-1] & H311 Toxic in contact with skin \\
& H301 Toxic if swallowed \\
& H318 Causes serious eye damage \\
& H317 May cause an allergic skin reaction \\
& H400 Very toxic to aquatic life \\
& H410 Very toxic to aquatic life with long-lasting effects \\
& H302 Harmful if swallowed \\
& H319 Causes serious eye irritation \\
& H315 Causes skin irritation \\
H400 Very toxic to aquatic life \\
H410 Very toxic to aquatic life with long-lasting effects \\
\hline H312 Harmful in contact with skin \\
H302 Harmful if swallowed \\
H335 May cause respiratory irritation \\
H315 Causes skin irritation \\
H318 Causes serious eye damage \\
\hline 1-Naphthol
\end{tabular}

The goals of these collaborative efforts between institutions and laboratories in different countries are the more effective coordination of supervisory actions as well as the adoption of criteria that are as homogeneous as possible.

The purpose of the European Society of Tattoo and Pigment Research, in collaboration with producers and tattoo parlours, is the sharing of methods and objectives for improving the safety of these products.

The activities planned in Italy in the next few years will be oriented according to the following main guidelines: a. Proposal of a single method, which is in accordance with guidelines of the national authorities, for the determination of different hazardous substances, among which are first-stage aromatic amines, polycyclic aromatic hydrocarbons and heavy metals.

b. Consideration of the adoption of limits for the concentrations of the aromatic amines listed in ResAP.

c. The extension of measures to restrict the levels of other hazardous aromatic amines, as a consequence of their high percentage of occurrence in the analysed samples, such as for the example substances listed in table 5 . 


\section{References}

1 Council of Europe: Resolution ResAP(2008) 1 on requirements and criteria for the safety of tattoos and permanent make-up (superseding Resolution ResAP(2003)2 on tattoos and permanent make-up), Adopted by the Committee of Ministers on 20 February 2008 at the 1018th meeting of the Ministers' Deputies.

2 European Commission: Directive 2001/95/EC of the European Parliament and of the Council of 3 December 2001 on General Product Safety.

3 Gregory AR: The carcinogenic potential of benzidine-based dyes. J Environ Pathol Toxicol Oncol 1984;5:243-259.

4 Kennelly JC, Hertzog PJ, Martin CN: The release of 4,4'-diaminobiphenyls from azodyes in the rat. Carcinogenesis 1982; 3:947-951.
5 Cerniglia CE, Freeman JP, Franklin W, Pack LD: Metabolism of azo dyes derived from benzidine, $3,3^{\prime}$-dimethylbenzidine, and $3,3^{\prime}$-dimethoxybenzidine to potentially carcinogenic aromatic amines by intestinal bacteria. Carcinogenesis 1982;3:1255-1260.

6 Dewan A, Jani JP, Patel JS, Gandhi DN, Variya MR, Ghodasara NB: Benzidine and its acetylated metabolites in the urine of workers exposed to Direct Black 38. Arch Environ Health 1988;43:269272.

7 European Union: Regulation (EC) No $1272 / 2008$ of the European Parliament and of the Council of 16 December 2008 on classification, labelling and packaging of substances and mixtures, amending and repealing Directives 67/548/EEC and 1999/45/EC, and amending Regulation (EC) No 1907/2006.

8 IARC Monographs Working Group on the Evaluation of Carcinogenic Risks to Humans: IARC Monographs on the Evaluation of Carcinogenic Risks to Humans: Volume 99: Some Aromatic Amines, Organic Dyes, and Related Exposures. Lyon, International Agency for Research on Cancer, 2010.
9 AGCIH - American Conference of Governmental Industrial Hygienists, www. acgih.org (accessed August 2012).

10 ISO: ISO 17234-1:2010: Leather Chemical tests for the determination of certain azo colorants in dyed leathers Part 1: Determination of certain aromatic amines derived from azo colorants. Geneva, ISO.

11 ISO: EN 14362-1:2012: Textiles - Methods for determination of certain aromatic amines derived from azo colorants Part 1: Detection of the use of certain azo colorants accessible with and without extracting the fibres. Geneva, ISO.

12 Agnello M, Fontana M, Mulatero G: Aromatic amines in tattoo inks: surveillance activities in Italy, 1st European Congress of Tattoo and Pigment Research, Copenhagen, 2013.

Marco Fontana

ARPA Piemonte, Regional Agency of Environmental Protection, Igiene Industriale

Via Sabaudia, 164

IT-10095 Grugliasco (Italy)

E-Mailm.fontana@arpa.piemonte.it 